\title{
Role of Government in eradication of Rural Poverty and Enhancing Employment in India
}

\author{
Alka Sharma* and Himanshu Agarwal**
}

Rural employment is not up to satisfactory level and most of the villagers are facing the severe problems of different types of unemployment due to that a large number of the youths are turning to unethical activities. Many literate, skilled and willing people are looking for the employment but their all efforts are like the tracing of needle in the dark. Though there are many types of unemployment prevailing in our society. The most widespread type of unemployment is disguised unemployment. It is a situation in which more people are engaged in an activity than the required ones. The people who are actually engaged in such as activity appear to be employed but in real sense they are not fully employed. This problem is particularly acute in rural areas. It is also known as underemployment. The absence of alternative employment opportunities in rural areas leads to this situation. Government should take strong action to overcome such problems because the target set in the present years to achieve the growth rate of 9 to $10 \%$ can be attained through the overall development of all the sectors of the economy and the fruits of economic development are shared by every citizen of our country. Hard decisions should be taken to compete in the race of economic development in the world, otherwise the gap between the urban and the rural prosperity will become biggest obstacle in our peace and prosperity.

[Keywords : Rural Economy, Population Growth, Unemployment, Poverty, Poverty Alleviation]

* Research Scholar, Faculty of Commerce and Business Administration, D. N. College, Meerut, Uttar Pradesh (India)

* Associate Professor, Faculty of Commerce and Business Administration, D. N. College, Meerut, Uttar Pradesh (India) E-mail: <drhimag@gmail.com> 


\section{Introduction}

Employment has in itself the fruits of prosperity and development of the rural economy as well as the country as a whole. Employment can be helpful in removing the problems of poverty, illiteracy among the rural poor and superstitious people which would ultimately help in maintaining their decent standard of living. This will in turn help in the best utilization of the available resources like financial, human and natural resources. It will also help in the economic security and stability of the rural section.

But the present status of rural employment is not up to satisfactory level and most of the villagers are facing the severe problems of different types of unemployment due to that a large number of the youths are turning to unethical activities. Many literate, skilled and willing people are looking for the employment but their all efforts are like the tracing of needle in the dark. Though there are many types of unemployment prevailing in our society. The most widespread type of unemployment is disguised unemployment. It is a situation in which more people are engaged in an activity than the required ones. The people who are actually engaged in such as activity appear to be employed but in real sense they are not fully employed. This problem is particularly acute in rural areas. It is also known as underemployment. The absence of alternative employment opportunities in rural areas leads to this situation.

Though, population growth is also considered as one of the major cause of unemployment in India. Population in India has increased at a rapid rate, but the employment opportunities have not increased to that extent due to slow pace of economic development. The rapid population growth has created an army of labour force. Effective and meaningful measures are needed to control population. This needs to be accompanied by creation of necessary conditions for employment opportunities particularly in rural areas.

\section{Rural Poverty in India}

"Meeting the needs of present without compromising the ability of future generations to meet their needs", was a definition produced by the Brundtland report (WCED, 1987). Stephen Lewis, former Canadian ambassador to the United Nations points out that the message of the Brundtland Report, which spoke on issues of the poor and the homeless, and of literacy and of the vulnerable and the disadvantaged, has largely been disregarded by Western society which is interested in balance sheets and in whether a given project results in more or less than "permissible" levels of environmental degradation.

There is a higher incidence of poverty in rural areas as compared to urban areas. This is testified by the Planning Commission's estimate for 2011-12 that 25.7 per cent of the rural population was living below the poverty line (Rs 816 per capita per month for rural areas) while for urban areas the proportion was 13.7 per cent of 
the population being below the poverty line (Rs 1,000 per capita per month for urban areas). Thus while more than a tenth of the urban population was living below the urban poverty line in 2011-12, a quarter of the rural population was living below the rural poverty line (Planning Commission, 2013). Poverty alleviation programmes in India thus become important especially in the case of rural India.

\section{Rural Poverty in the Planning Process}

Poverty is one of the most Important problems that India is facing today poverty is a situation in which a person in unable to get minimum basic necessities of life, i.e. food, clothing and shatter for his or her substance. In our daily life, we come across many people who we think are poor. They could be landless labourers in villages or people living in overcrowded jhuggies in cities. They could be daily wage workers at construction cities or child workers in dhabas. They could also be beggars with children in tatters. We see poverty all around us. In fact, every forth person in India is poor. This means, roughly 260 million (or 26 crore) people in India live in poverty. This also means that India has the largest single concentration of the poor in the world.

Mahatma Gandhi always insisted that India would be truly independent only when the poorest of its people become free of human suffering. At line centre of the discussion poverty is usually the concepts of the poverty line.

In rural areas, geographical factors as an externality can be predominant in influencing poverty, as for example, in how droughts can act to increase rural poverty by decreasing incomes from agricultural production. There can also be issues over the delivery of institutional quality in remote rural areas. Institutional quality can affect poverty alleviation and this is brought out in a study by Perera \& Lee (2016) The study found that while some aspects of institutional quality such as improvements towards a stable government and a better law and order regime act to reduce poverty, other aspects such as improvement, in bureaucratic quality and democratic accountability along with corruption act to increase poverty due tc their association with an increase in the inequality of income distribution.

It can be added that improvements in bureaucratic quality and democratic accountability make the economic system more centrally determined, thus negating a multi-determined economics whereby income distribution can be more centrally determined unless policy leads otherwise. The correct policy configuration, however, can act to foster more equitable income distribution. This necessitates the penetration of public policy in poverty alleviation programmes in India. While in urban areas the policy infrastructure can be more far reaching, in rural areas great attention is required in terms of delivery mechanisms of public policy. There can be issues over the delivery of institutional quality in rural locations in India due to their distance from hubs of policy organization. poverty 
alleviation programmes in India that have a focus on rural poverty can greatly assist public policy in working for the betterment of the rural populations.

India has a legacy of high incidence of poverty, and as such it is considered a very important aspect of the developmental process in India by policymakers in the planning process. The Niti Aayog, the chief planning body for the Government of India has a Task Force dedicated to this purpose. In estimating poverty however, the first step is enumeration of poverty, and in this fixing a poverty line (with incomes below, which coming under the category of absolute poverty) becomes very important, and its exact value is usually widely debated after being fixed. On the basis of market prices in 1960-61, the earliest poverty line for rural populations was fixed at Rs. 20 per capita per month. Although it was not the official poverty line, it led to extensive discussions on estimating poverty in the planning commission of India.

These discussions on poverty in India culminated in an expert committee being appointed by the planning commission 1n 1977 under the economist Y. K. Alagh that looked to produce a methodology for measuring poverty in India. A report was submitted by the committee in 1979 that set the rural poverty line at Rs 49.09 per capita per month in terms of market prices of 1973-74. The report also suggested setting different rural and urban poverty lines. This was followed by the Lakdawala Committee which suggested a methodology to update the poverty lines over time in 1993. The Alagh and Lakdawala committee recommendations remained the basis for national estimates on measuring poverty until 2004-05. Towards the end of 2005, the Planning commission appointed the Tendulkar committee which submitted its report in $200 \mathrm{~g}$ which made upward adjustments to the poverty line such that it could be updated. What is now referred to as the Tendulkar poverty line is used in estimating the poverty line in India (Niti Aayog, 2016).The values used in the poverty line however, remain a contentious issue.

The poverty line can play a very crucial role in certain poverty alleviation programmes in India in the Identification of poverty, the regional tracking of poverty and in estimations of expenditure for these programmes, Although the poverty line plays a crucial role in targeted poverty alleviation programmes it is not important in universal poverty alleviation programmes. In universal poverty alleviation programmes it India the benefits of the programme can be available to all rural households and are not hugely depended on exact estimates of poverty. An example of a universal poverty alleviation programme is the Mahatma Gandhi National Rural Employment Guarantee Act (MNREGA). In targeted programmes information on poverty is necessary and expenditure allocations are sometimes made on alternative criteria that do not depend on estimates of the poverty line used.

While determining the poverty line in India, a minimum level of food requirement, clothing, footwear, fuel and light education and medical requirement 
etc. are determined for subsistence. These physical quantities are multiplied by their prices in rupees the present formula for food requirement while estimating the poverty line is based on the desired calories requirement. Food items such as pulses, vegetables, milk, oil, sugars depending on age, Sex and the type of work that a person does the accepted average calories requirement in India is 2400 calories per person per day in rural areas. The ratio of poor people is not the same in every state, although state level poverty has witnessed a secular decline from the levels of early seventies, the success rate of reducing poverty varies from state to state. Recent estimates show that in 20 states and Union territories, the poverty ration is less than the national, average on the other hand, poverty is still a serious problem in Orissa, Bihar, Assam, Tripura and U.P. Orissa and Bihar continue to be the two poorest states with poverty rations of $47 \%$ and $43 \%$ respectively.

Removal of poverty has been one of the major objectives of India development strategy. The current anti poverty strategy of the government is based broadly on two plans. 1. Economic growth 2. Targeted anti-poverty programmes.

\section{Rural Poverty Alleviation Programmes in India}

Several poverty alleviation programmes in India meant to address poverty alleviation directly or indirectly have been launched by the incumbent government such as the Pradhan Mantri Jan Dhan Yojana (PMJDY) - a financial Inclusion scheme, the Pradhan Mantri Gramin Awaas Yojana - a housing scheme for the rural poor, the Atal Pension Yojana (APY) - aimed at increasing pension scheme beneficiaries in India, the Sansad Adarsh Gram Yojana (SAGY) - aimed at fostering infrastructure development in rural areas, the Pradhan Mantri Fasal Bima Yojana (PMFBY) - a crop insurance scheme, the Pradhan Mantri Gram Sinchai Yojana aimed at attracting irrigation investments, the Deen Dayal Upadhyaya Grameen Kaushalya Yojana (DDUGKY) - for skill development of rural youth, being some examples (Sarkari Yojana, 2018).

Many of these schemes are quite nascent and performance evaluations of these schemes are rather difficult. In the decades shortly after the turn of the century, the Mahatma Gandhi National Rural Employment Guarantee Act (MGNREGA) and the Public Distribution system (PDS) are prominent examples of the running policies for poverty alleviation in rural India. Before the MGNREGA and the PDS working under new legislation, the Integrated Rural Development Program (IRDP), the Mid-Day Meal Scheme (MDMS), the National Family Benefit Scheme (NFBS) and the National old Age pension scheme (No Aps) represent some of the older schemes aimed at benefitting poor people in rural India. The MGNREGA came into force in 2006 and the scheme guarantees 150 days of paid work a year to people in rural areas. The policy aims to improve opportunities for rural people in gaining employment by providing guaranteed wage employment 
for unskilled manual work. By 2018, 1.5 million households were registered under the MGNREGA (Ministry of Rural Development, GOI, 2018).

The Public Distribution system (PDS) is another programme that helps in improving the quality of life of impoverished populations in India. The National Food security Act (NFSA), 2013 ties up with the PDS for distribution of food in India for providing subsidized food grains. About 50 per cent of the urban population and about 75 per cent of the rural population is covered by the purview of the Act and beneficiaries are entitled to receive $5 \mathrm{~kg}$ of food grains in a month per person at subsidized rates of Rso 3/2/1per $\mathrm{kg}$ of rice, wheat or coarse grains respectively. The Act has been implemented in all of the states and union territories in India and the government claims that out of a coverage target of 13.4 million people, the policy has reached 807.2 million people in total for both rural and urban areas (GOI, 2018). There are some discrepancies however, over the implementation of certain provisions of the Act by some state s (ET, 2017).

An example in terms of an older government scheme for the benefit of rural India is the Integrated Rural Development Programme (IRDP). The policy came into force in 1979 and aimed to help micro-enterprises by extending loans to beneficiaries for the purchase of assets and by subsidizing asset costs by between 25 and 50 per cent. Although some of the poor made moderate progress as a result of the policy, the IRDP has succeeded in helping only 1 in 5 people in crossing the poverty line (Saxena, 2013). Some rural poverty alleviation programmes in India are listed below :

Table-1 : Government Programmes to Eliminate the Poverty

\begin{tabular}{|l|l|c|}
\hline \multicolumn{1}{|c|}{ Name of Programme } & \multicolumn{1}{|c|}{ Purpose } & $\begin{array}{c}\text { Date of coming } \\
\text { into force }\end{array}$ \\
\hline $\begin{array}{l}\text { Integrated Rural Develop- } \\
\text { ment Programme (IRDP) }\end{array}$ & $\begin{array}{l}\text { Helping micro-enterprises by extending } \\
\text { loans to beneficiaries for the purchase of } \\
\text { assets and by subsidizing asset costs. }\end{array}$ & 1979 \\
\hline $\begin{array}{l}\text { Public Distribution System } \\
\text { (PDS) }\end{array}$ & $\begin{array}{l}\text { Distribution of subsidized food and } \\
\text { non-food items to India's poor. }\end{array}$ & 1992 \\
\hline $\begin{array}{l}\text { Mid-Day Meal Scheme } \\
\text { (MDMS) }\end{array}$ & $\begin{array}{l}\text { Providing meals to school children and } \\
\text { improving their nutritional status. }\end{array}$ & 1995 \\
\hline $\begin{array}{l}\text { National Family Benefit } \\
\text { Scheme (NFBS) }\end{array}$ & $\begin{array}{l}\text { Financial compensation provided to kin } \\
\text { in case of the natural death of a below } \\
\text { poverty line primary breadwinner. }\end{array}$ & 1995 \\
\hline $\begin{array}{l}\text { National Old Age pension } \\
\text { Scheme (NOAPS) }\end{array}$ & A pension scheme for people of old age. \\
\hline $\begin{array}{l}\text { Mahatma Gandhi National } \\
\text { Rural Employment Guara- } \\
\text { ntee Act (MGNREGA) }\end{array}$ & $\begin{array}{l}\text { Help in providing livelihood security by } \\
\text { guaranteeing minimum days of work for } \\
\text { rural labour. }\end{array}$ & 2006 \\
\hline
\end{tabular}




\begin{tabular}{|l|l|c|}
\hline $\begin{array}{l}\text { Pradhan Mantri Jan Dhan } \\
\text { Yojana (PMJDY) }\end{array}$ & $\begin{array}{l}\text { To ensure financial inclusion by } \\
\text { ensuring access to financial services in an } \\
\text { affordable manner. }\end{array}$ & 2014 \\
\hline $\begin{array}{l}\text { Pradhan Mantri Gramin } \\
\text { Awaas Yojana }\end{array}$ & A housing scheme for the rural poor. & 2017 \\
\hline
\end{tabular}

With greater revenue available for social programmes, policy-makers can now look forward to more far- reaching poverty alleviation programmes in India. The Niti Aayog constituted a task force for the elimination of poverty on March 16, 2015 headed by Dr. Arvind Panagariya, the vice chairman at the Niti Aayog. Using the methodology described by the recommendations of the Tendulkar committee, the task force fixed that those earning less than Rs. 27.20 in rural areas are below the poverty line. The estimate was controversial and generated much debate in policy circles. Based on these estimates which fixed the poverty line in urban areas at Rs. 33.33 per day in urban areas in addition to the low income in rural areas, 22 percent of the people in the country could be classified as poor (ET, 2017). Many believed that the proportion of the poo can be much larger in India while others questioned the extremely low income cited as the poverty line. This is important since many of the government's rural poverty alleviation programmes in India are target schemes.

In contemporary times enumerative devices such as one's UIDAI is also assuming importance in terms of policy orientation in rural poverty alleviation programmes in India. For example, after the 20j5-16 budget, insurance schemes were introduced that made use of bank accounts linked to the Adhaar scheme. New poverty alleviation programmes in India such as the Jan Dhan Yojana make use of Adhaar identification. The UIDAI in poverty alleviation can be important given that many of the target beneficiaries do informal work. It can also help in establishing regimes of identification for poorer people at the margins such that their needs can be addressed by policy. Using one's Adhaar card to collect compensation in the event of a natural disaster such as floods is one example.

The use of mobile cum banking is also gaining prominence in financial transactions although many in rural India still prefer d6aling in cash. One good however, is that access to cash has been made easier in rural areas by the Intervention of government schemes. The problem for rural areas has for a long time been a lack of access to financial support or opportunities. Rural poverty alleviation programmes in India look to improve access to employment, food, finances and other such basic needs for people in rural India, many of whom can sometimes live in remote areas outsole the purview of large-scale development. A basic needs approach is all the more necessary in addition to fixing a poverty line in rural areas given that access to developmental processes and facilities might be more limited in far-flung rural areas. 
With the advent of foreign capital in our country, the cities have abundant employment but the rural people are still short of these opportunities. Many business men are establishing their industries near the cities, neglecting the rural people which lead to the economic instability in our country. Due to lack of employment opportunities in rural areas many qualified people are forced to do low level jobs, which is waste of our talent. Many educated people of rural areas are working as labourers too.

To remove this burning problem, government should take some hand-care decision's government should take effective measures to check from time to time the development of the plans and policies announced for the rural people.

Government should take strong action to overcome such problems because the target set in the present years to achieve the growth rate of 9 to $10 \%$ can be attained through the overall development of all the sectors of the economy and the fruits of economic development are shared by every citizen of our country. Hard decisions should be taken to compete in the race of economic development in the world, otherwise the gap between the urban and the rural prosperity will become biggest obstacle in our peace and prosperity.

\section{References}

Buhmann, B., Rainwater, L., Schmaus, G. and T. Smeeding, “Equivalence Scales, Well-Being, Inequality and Poverty : Sensitivity Across Ten Countries Using the Luxembourg Income Study (LIS) Database", Review of Income and Wealth, 94, 1988, 115-142.

Buvinic, M. and G. R. Gupta, "Female-Headed Households and Female-Maintained Families: Are They Worth Targeting to Reduce Poverty in Developing Countries?", Economic Development and Cultural Change, 45(2), 1997, 259-280.

Chaudhuri, S. and M. Ravallion, "How Well Do Static Indicators Identify the Chronically Poor?", Journal of Public Economics, 53, 1994, 367-394.

Coulter, F. A. E., Cowell, F. A. and S. P. Jenkins, "Equivalence Scale Relativities and the Extent of Inequality and Poverty", Economic Journal, 102, 1992, 1067-82.

Datt, G. and M. Ravallion, "Why Have Some Indian States Done Better Than Others at Reducing Rural Poverty?", Economica, 65, 1998, 17-38.

Dreze, J. and P. V. Srinivasan, "Poverty in India: Regional Estimates 1987-88", Discussion Paper No. 70, London School of Economics - STICERD, February 1996.

Dreze, J. and P. V. Srinivasan, “Widowhood and Poverty in Rural India: Some Inferences from Household Survey Data", Journal of Development Economics, 54(2), 1997, 217-234.

Dubey, A. and S. Gangopadhyay, Counting the Poor: Where Are the Poor in India?, Sarvekshana, Analytical Report Number 1, Department of Statistics, Government of India, 1998.

Galbraith, J. K., The Nature of Mass Poverty, Cambridge : Harvard University Press, 1979.

Lancaster, G., Ray, R. and R. Valenzuela, "A Cross Country Study of Household Poverty and Inequality on Unit Record Household Budget Data", Economic Development and Cultural Change, 48(1), 1999, 177-208. 
Lanjouw, P. and M. Ravallion, "Poverty and Household Size", Economic Journal, 105, 1995, 1415-1434.

Meenakshi, J.V. and R. Ray, "Regional Differences in India's Food Expenditure Pattern: A Complete Demand Systems Approach", Journal of International Development, 11, 1999, 47-74.

Minhas, B. S., Jain, L. R., Kansal, S. M. and M. R. Saluja, “Rural Cost of Living : 1970-71 to 1983, States and All India", Indian Economic Review, 25(1), 1990, 75-104.

Nelson, J. A., "Household Economies of Scale in Consumption: Theory and Evidence", Econometrica, 56, 1988, 1310-1314.

Nolan, B. and C. T. Whelan, Resources Deprivation and Poverty, Oxford : Clarendon Press, 1996.

Pollak, R. A. and T. J. Wales, "Welfare Comparisons and Equivalence Scales", American Economic Review, 69(2), 1979, 216-221.

Pollak, R. A. and T. J. Wales, Demand System Specification and Estimation, Oxford : OUP, 1992.

Rao, V. V., "Measurement of Deprivation and Poverty Based on the Proportion Spent on Food", World Development, 9(4), 1981, 337-353.

Ringen, S., "Households, Standard of Living, and Inequality", Review of Income and Wealth, 37(1), 1991, 1-13.

Article Received on July 19, 2018; Accepted on September 12, 2018 